\title{
A Study on Sociocultural Attitudes and Appearance Management Behavior in accordance with Gender Role Identity ${ }^{+}$
}

\author{
Park Eunhee \\ Lecturer, Dept. of Fashion Design, Daegu University
}

\begin{abstract}
The purpose of this study was to classify types in sense of gender role identity and to figure out the difference among sociocultural attitude, benefits of clothing pursuit, and appearance management behaviors by sense of gender role identity types.

Questionnaires were administered to 455 people in their twenties and thirties living in Daegu and Kyoungbuk area. Data were analyzed by using frequency, factor analysis, credibility, $X^{2}$-test, ANOVA, Duncan-test, and t-test.

The findings are as follows.

First, Men of androgyny group showed the highest rate of $38.5 \%$ followed by undifferentiation(22.9\%), masculineness(21.0\%), and feminineness(17.6\%). Women of undifferentiation group showed the highest rate of $33.2 \%$ followed by feminineness (25.2\%), androgyny(22.0\%), and masculineness(19.6\%).

Second, factors of sociocultural attitude were internalization and recognition. Benefits of clothing pursuit consists of the factors such as consciousness of others, personality, and vogue pursuit. Factors of appearance management behaviors were dressing, skin management, plastic surgery management, weight management, health management, and hair management.

Third, the result from the difference between sociocultural attitude and benefits of clothing pursuit by sense of gender role identity types, men of androgyny and feminineness showed highest in recognition while women of androgyny showed highest in internalization and recognition. The result of the difference in benefits of clothing pursuit by sense of gender role identity shows that both men and women of androgyny group have high tendency for being conscious of others, personality pursuit, and vogue pursuit while men of undifferentiation and masculineness have low interest in dressing in relationship with others.
\end{abstract}

\footnotetext{
${ }^{+}$This study was supported by the National Research Foundation of Korea with the finance of government(Ministry of Education and Science) 2011.(NRF-2011-35C-G00103)

Corresponding author ; Park Eunhee, Tel. +82-53-950-6220, Fax.+82-53-950-6219

E-mail : parkh1987@hanmail.net
} 
Fourth, the examination of the difference in appearance management behavior by sense of gender role identity types found men of androgyny group managed dressing, skin, weight, health and hair most while women dress and health most. Men of undifferentiation group managed dressing and weight least, while men of masculineness health, and men of feminineness hair least.

Key Words : Gender Role Identity, Sociocultural Attitudes, Benefits of Clothing Pursuit, Appearance Management Behavior

\section{Introduction}

The changes of social structure and the development of science and technology in 20th century have changed the gender role into a fluid one. Sociocultural changes such as an increase of women's entry in public affairs caused by expanded chance of women's education, women's movements, idea of gender equality, decrease of birth rate, decrease of women's housework, and nuclear family have made clear difference of gender role obscured and justification for existence of existing gender role disappeared. Along with these changes, getting into the post-modern society, the sense of gender role identity has been obscured and the abolishment of patriarchal family system as well as vigorous entry of women in public affairs has led a trend of an increase in the number of women with male gender identity or men with female gender identity.

Like this, it would be better if the gender role is considered in the way that finds an ideal model of sharing both gender not in the way that finds a superiority from the conflicting view point. In this way, an androgyne is the one that contains the characteristics of both gender, who can have a free choice of a gender role according to a situation. ${ }^{1)}$

Especially the concept of gender role can have influence on definition or judgement toward beauty, which also is connected to the satisfaction with body or appearance according to expected ideal appearance or body shape of men and women and affects clothing behavior to which gender role identity is reflected. ${ }^{2)}$

According to Kim Yongsook, androgyne and masculine groups are highly interested in eye and lip makeup to show individuality and sense of self-confidence as they have strong desire to express them. ${ }^{3)}$

Choi Miyoung found that the dynamic consumption behavior of girl students in university can be explained by active emotion pursuit which is more flexible toward gender role, self-initiated masculinity, directivity toward open gender role. In traditional feminineness pursuit which is represented as dependent and receptive tendency, a behavior considering others and social dangers is expressed rather than an active interest about fashion and clothing. ${ }^{4)}$ Likewise the appearance can be related to gender role identity such as androgyny, masculinity, feminineness and undifferentiation, and it would be meaningful to examine gender role identity and appearance managing behavior by gender.

An individual accepts sociocultural standards through mass media such as TV, magazines and music videos, and pursues appearance 
Park Eunhee / A Study on Sociocultural Attitudes and Appearance Management Behavior in accordance with Gender Role Identity

managing behavior by internalizing them as his/her own. The ideal beauty conveyed through mass media valuates his/her body and internalizes the value, which becomes a evaluation standard to form a sociocultural attitude. This sociocultural attitude makes people compare themselves more with others, which leads him to comparing and being conscious of others. The result led by this process will differ by the types of gender role identity.

Existing studies related to this gender role identity are found with subjects of men ${ }^{5 / 6) 7 / 8) 9 \text { ), }}$ women ${ }^{1011) 12)}$, boys and girls ${ }^{13) 14}$, but seldom found with subjects of men and women in their 20 s to 30 s classifying the types of gender role identity.

People in their 20 s and 30 s in these days tend to be free and open in expressing themselves due to diversification of lifestyle and active attitude toward life. The appearance turns out to be an important tool for expressing themselves and to be a core cue for evaluation of others. ${ }^{15)}$

Accordingly, this study is to examine men and women separately and to find out how they manage their appearance by the types of gender role identity by grasping the sense of gender role identity in them as they put a bigger emphasis on appearance in finding out their own roles in a society, preparing for a new job or forming a relationship needed for social behavior.

\section{The background of the theory}

\section{Gender Role Identity}

According to a study of Bem, 35\% of university student subjects had characteristics of the opposite gender, and those who have both strong masculinity and feminineness were termed as androgyny. From the viewpoint of psychological and sociological adaptation, this androgyny is said to have a stronger adaptability and to be desirable. ${ }^{16)}$

In other words, androgyny means a desirable masculinity and a desirable feminineness from the contents of stereotypes for gender role in society are combined and coexist. Sense of gender role identity refers to a kind of self-description where the expected value of socioculturally accepted or allowed masculinity and feminineness is internalized as a personality characteristics of an individual. This gender role identity affects the attitude, the way of thinking, and behavior of an individual and it plays an important role in structuring a personality.

Therefore, sense of gender role identity refers to the level and type of masculine characteristics and feminine characteristics appeared in each individual behavior and personality which might be same as or different from the stereotype of gender role as a facet of personal sense of identity. ${ }^{17)}$

According to Lee Younjung, 2 masculine factors(dymanics, taciturnity) and 3 feminine factors(mildness, scrupulosity, affableness) are driven for the factors of gender role identity and are measured by KSRI embracing several sub-dimensions.

A strong view of western-style masculineness plays more dominant role in defining masculineness in Korean society than a taciturn and rigorous nature emphasized in a Confucian culture. Men usually showed very receptive manner on mild or meticulous personality nature which belong to feminine factors. ${ }^{18)}$

Lee Misook found that an androgyne type of gender role identity is distributed most among both boy and girl students in high school. These 
students with androgyny are interested more in clothing than other gender role types and they put emphasis on ostentation and comfort of clothing while they don't consider sympathy much. ${ }^{19)}$

In Ku Yangsuk, Lee Young Ju and Choo Taegue's study, androgyny was shown highest in the twenties and lowest in the thirties. Masculineness was shown highest in the forties while low in the twenties and the thirties and undifferentiation was found comparatively high in the thirties and forties. This result tells that the younger the more chance of accommodating the idea that men can be feminine out of the fixed idea about typical gender role and due to the influence of mass media men shows metro-sexual phenomena which refers to men have more interest in fashion and appearance. ${ }^{20)}$

This way we can comprehend that the sense of gender role identity differs in its distribution of types according to culture, gender type, and age and that different personal nature can be found in every individual.

The sense of gender role identity refers to a characteristics considered to be desirable by males and females proper to social expectations. This study tries to divide this concept into 4 types regardless of natural gender; feminineness, masculineness, androgyny which can have characteristics of both and undifferentiation in which the characteristics of both are relatively low.

\section{Sociocultural Attitudes and the Benefits of Clothing pursuit.}

Leslie J. Heinberg, J. Kevin Thompson, and Susan Stormer developed SATAQ(sociocultural attitude towards appearance questionnaire), the measure for the women's recognition and accommodation level of appearance standards which are socially forced and empirically examined. $^{21)}$

This is an internalized one by recognizing the beauty of a body suggested by mass media and accepting the standards. In other words, an ideal image of a body exists in culture and standards for beautiful or attractive points of a person rely on the ideal of a culture where he/she belong.

An ideal body of a culture is not immortal but changeable through period of time and the standards for this spread widely through mass media. This way, a person who recognized and internalized the sociocultural standards for a slim body shape through mass media would pursue appearance managing behavior accordingly. That is to say women in their 20s and 30s were experiencing various appearance managing behaviors very actively. In these days lookism is rampant in our society and this appearance gets more important for a social position and job achievement, which might change the sociocultural attitude toward appearance even in men.

According to Lee Seunghee and Lee Siweon, women had more tendency to internalize the ideal standards delivered through mass media, put more emphasis on social importance of appearance, and showed more appearance managing behaviors than men in the difference of sociocultural influence by gender type. ${ }^{22)} \mathrm{Kim}$ Yongsook found women of androgyny had most interest in appearance-interest and appearance -attraction and the body image of an undifferentiated group showed lowest comparing to other groups. ${ }^{23)}$ According to Nam Sujung, the sociocultural attitude toward appearance had the most relative influence on metro-sexual consumption tendency compared to other factors. With this result, Nam suggested this showed the fact that metro-sexual consumption 
Park Eunhee / A Study on Sociocultural Attitudes and Appearance Management Behavior in accordance with Gender Role Identity

can be largely different according to the attitude toward sociocultural pressure rather than to psychological factors inside just like gender role identity and sense of self-respect. ${ }^{24)}$

Sociocultural attitude means the internalization of self-value recognizing the standards of sociocultural beauty through mass media. This might be different from existing researches considering different standards of appearance by the sociocultural environment rather not personal psychological factors.

As clothing has a function of increasing self -confidence through psychological satisfaction as well as an instrumental function for compensating a body shape or increasing appearance, choosing and wearing clothes has big impact on personal relations.

The clothing has a direct influence on evaluation and feeling of personal appearance as an extension of a body since clothing involves a shared sociocultural meaning and makes up a part of appearance and has a close connection to a body. Accordingly a wanted subjective compensation or an expected positive result of choosing and wearing clothes can be different by the situation of usage or consumer characteristics.

Pursuit benefit refers to needs and wants which consumers directly feel related to properties of specific products meaning a subjective compensation or expected positive results that consumers want related to usage of products. The benefits of clothing pursuit divided into two groups; functional dimension such as price, practicality, economic feasibility, quality and etc. and psychological dimension such as self expression, personality, brand and etc. and experiential dimension such as dignity/ gentleness, sexual charms/ladyishness, pleasure and etc.
Lee Yoonjung found that the higher perceived masculineness, the more pursuing fashionableness in clothing, the higher syntone and the more pursuing personality, the more managing appearance, therefore people who have high perceived masculineness manages appearance more. ${ }^{25)}$

Clothing has sociopsychological properties, which bring differentiated properties of personal pursuit according to changes in gender role. This study tries to deal with being conscious of others, personality pursuit and vogue pursuit as sub-variables of the benefits of clothing pursuit.

\section{Appearance Management Behavior according to Gender Role Identity}

Recent changes of gender role in youth are noticeable. As we can get to know from the terms like 'Alpha girl'(A woman who is superior to men at her age in every side), 'Gold Miss'(A woman in her 30s who enjoys solo life investing on self-development based on a solid job and economic power), Beta Man(a man who assists an alpha girl very well), 'Pet-man'(a man who is so cute and well-following of a woman like a pet) and etc., women are actively working in many parts which have belonged to men and on the other hand, men who were traditionally negative in managing and decorating appearance are now they devote their time and effort to manage their appearance. ${ }^{26)}$

This shows an inescapable phases of the times which is the image of a changing society breaking from convention. Like this, it's meant to be in the process of women's gender role being wide and changing and it's a new discovery and it can be explained by destruction of a structured society fitting men from a viewpoint of the ones who have vested rights.

The result suggested women who have 
feminineness developed with trained masculineness can be free from a traditional women's role with some flexibility in a changing social value system. ${ }^{27)}$ Lee Yoonjung considered that men consumers' getting interested in appearance and managing their own appearance does not mean something feminine or losing masculineness rather it means that they have strong masculineness. ${ }^{28)}$

An idea about beauty and ideal beauty has been changed with the changes of social, economical, cultural environments and beauty or ideal beauty of women than men has been embossed. But the discrimination of gender role got ambiguous and each gender plays his/her best in any parts of work, the differentiation in this beauty got disappeared.

Men got interested in appearance management such as in fashion or beauty area as well as leisure or travelling since the economy is getting better and more space in life is secured. Eyes on men also got flexible so that beauty can be recognized not only for women but as a kind of personal ability.

Social recognition on identity by a traditional fixed idea has been changed to an enforced feminineness based on multi-dimensional phenomena unlike past times. It can be said that appearance management does not separate men and women rather it depends on interest level.

An active lifestyle of people with desirable characteristics from both masculineness and feminineness have brought a phenomena of increased expectation and needs about health and beauty and getting better in economy. The more epicene, the more appearance management behaviors and it is needed to emphasize this androgyny on marketing of appearance management products especially for people in androgyne group. $^{29)}$

In Ku Yangsuk, Lee Young Ju and Choo Taegue's research, there was a significant difference in appearance management behaviors by the gender role type groups. That is, androgyny group showed higher score in factors of fashion, appearance improvement and health, and for the factors of bodyshape management and hair management were shown higher in androgyny group and masculineness group than in feminineness and undifferentiation group. The factors skin management and plastic surgery were higher in androgyny group and feminineness group than in masculineness and undifferentiation group. ${ }^{30)}$

The will to make oneself look more beautiful is locomotive for various appearance management behaviors. This can be caused from the way of thinking that appearance management behaviors can change some of original appearances. Therefore appearance management behavior means using tools or devices such as clothes, cosmetics, accessary and props to make oneself look to others as he/she expected.

\section{Methods}

\section{Research Questions}

1. Classification of types in sense of gender role identity.

2. Examination of significance in demographic characteristics by sense of gender role identity types.

3. Figuring out difference between sociocultural attitude and benefits of clothing pursuit by sense of gender role identity types.

4. Figuring out difference of appearance management behaviors by sense of gender role identity types. 
Park Eunhee / A Study on Sociocultural Attitudes and Appearance Management Behavior in accordance with Gender Role Identity

\section{Participants and Analysis}

The subjects of this study are 455 people in their twenties and thirties living in Daegu and Kyoungbuk area, which consists of 205 males (45.1\%) and 250 females(54.9\%). The sample also consists of 258 twenties(56.7\%) and 197 thirties(43.3\%). The sample showed a various rate of jobs such as 156 students (34.3\%), 21 housewives, 150 businessmen and businesswomen, 22 in professional fields, 49 production workers and 49 sales and service personnels.

The pilot test was done on March, 2012 for verifying questionnaire, and main survey work was done from May 10 to may 20. 480 surveys from 510 were received and total 455 surveys were used for examination using SPSS PC+ 18.0 for analysis of frequency, factor, credibility, $\mathrm{X}^{2}$-test, ANOVA, Duncan-test, and t-test.

\section{Measurements and Procedure}

This study used a research method by a questionnaire and measurement devices are like below;

Considering the fact that sense of gender role identity is not a solid concept since gender role as a social value standard changes according to culture, total 40 questions (20 for feminineness and 20 for masculineness) of KSRI(Korean Sex Role Inventory) were used with a sentence asking how well each question expresses yourself on 5 scores from 1(Never) to 5(Always).

Sense of gender role identity types were divided into 4 groups by median-split method; androgyny, masculineness, feminineness, undifferentiation. The median of masculineness is 3.20 and feminineness 3.35. With these medians, androgyny group(38.5\% male, 22\% female) is with people who have higher score than median in both masculineness and feminineness, masculineness group $(21.0 \%$ male and $19.6 \%$ female) with high masculineness and low feminineness, feminineness group $(17.6 \%$, $25.2 \%$ ) with low masculineness and high feminineness, and undifferentiation group(22.9\%, 28.6\%) with low in both.

Sociocultural Attitude toward Appearance refers to forming a sociocultural attitude by valuating and internalizing his/her body with ideal beauty delivered through mass media. Based on Leslie J. Heinberg, J. Kevin Thompson, and Susan Stormer's SATAQ(Sociocultural Attitude Toward Appearance Questionnaire) ${ }^{31)}$ and other previous studies, ${ }^{32) 33)}$ items were revised and modified into 11 questions with 5-score Likert measure.

Benefits of Clothing pursuit refers to the needs or benefits which he/she feels related to appearance and the questionnaire items for this concept were revised and modified into 15 questions with 5-score Likert measure. ${ }^{34)}$ Appearance management behaviors refers to the behavior of managing hair, skin and make-up and exercising or going on a diet for managing weight, choosing and wearing clothes for correction of body shape. Based on previous studies, ${ }^{35) 36)}$ items were revised and modified into 23 questions with 5-score Likert measure. Demographic variables are gender, age, and job.

\section{Results and Discussion}

\section{Types of Gender Role Identity}

In dispersion of subjects, <Table 1> shows the result of classification by sense of gender role identity. Men in androgyny group are the highest in rate, 38.5\%, which have a characteristics of trustful, sincere mind and strong will and at the same time a characteristics of soft and mild heart. Men of 
undifferentiation group who are not soft nor delicate with weak will and low locomotive are $22.9 \%$, and men of masculineness group who are of decision with high locomotive are $21.0 \%$, men of feminineness group who are just typical women with delicate emotion and softness showed the lowest rate, 17.6\%. In women's cases, women of undifferentiation group who have weak self-confidence and willingness and are not kind nor obedient showed the highest rate of $33.2 \%$ followed by feminineness $(25.2 \%)$, androgyny(22.0\%), and masculineness(19.6\%).

$<$ Table 2> shows the demographic characteristics by the types in sense of gender role identity and there was a significant difference in gender, age, and job. Men showed high in androgyny group while women in undifferentiation group. In the feminineness group, women were more than men while in the masculineness group showed an analogous gender rate.

In groups by age, twenties have androgyny in highest rate followed by feminineness while thirties have undifferentiation in highest rate followed by androgyny, which means the idea in younger ages is changing from a traditional one that men should be manly to a new one that men can be ladyish. This is also a reflection of the changing progress to metro-sexual phenomena that men gets more interested in fashion and appearance due to the influence of mass media supporting the result of Ku Yangsuk, Lee Young $\mathrm{Ju}$ and Choo Taegue's study. ${ }^{37)}$

In groups by job, students have feminineness in highest followed by androgyny, undifferentiation and masculineness, which might be resulted from the different gender rate among students. Employees have undifferentiation and androgyny in a similar rate while workers in sales and service area have androgyny in highest, which means people who are willing and obedient, trustful and kind at the same time are needed in the field.

\section{Factor analysis on Sociocultural Attitude, Appearance Management Behavior, and Benefits of Clothing Pursuit}

1) The factor structure of Sociocultural Attitude

$<$ Table 3> shows the result of factor analysis using Varimax rotation to figure out the sociocultural attitude structure of twenties and thirties.

Sociocultural attitude had two factors altogether explaining $61.30 \%$ of total variance and Cronbach's alpha coefficients ranged from

$<$ Table $1>$ Dispersion of types in gender role identity

\begin{tabular}{c|c|c|c|c|c}
\multicolumn{7}{c}{$n(\%)$} \\
\hline $\begin{array}{c}\text { Types in gender role } \\
\text { identity }\end{array}$ & Androgyny & Masculineness & Feminineness & $\begin{array}{c}\text { Undifferentiatio } \\
n\end{array}$ & Total \\
\hline Male & $\begin{array}{c}79 \\
(38.5 \%)\end{array}$ & $\begin{array}{c}43 \\
(21.0 \%)\end{array}$ & $\begin{array}{c}36 \\
(17.6 \%)\end{array}$ & $\begin{array}{c}47 \\
(22.9 \%)\end{array}$ & $\begin{array}{c}205 \\
(100.0 \%)\end{array}$ \\
\hline \multirow{2}{*}{ Female } & $\begin{array}{c}55 \\
(22.0 \%)\end{array}$ & $\begin{array}{c}49 \\
(19.6 \%)\end{array}$ & $\begin{array}{c}63 \\
(25.2 \%)\end{array}$ & $\begin{array}{c}83 \\
(33.2 \%)\end{array}$ & $\begin{array}{c}250 \\
(100.0 \%)\end{array}$ \\
\hline Total & $\begin{array}{c}134 \\
(29.5 \%)\end{array}$ & $(20.2 \%)$ & $(21.8 \%)$ & $(28.6 \%)$ & $(100.0 \%)$ \\
\hline \hline
\end{tabular}


Park Eunhee / A Study on Sociocultural Attitudes and Appearance Management Behavior in accordance with Gender Role Identity

$<$ Table 2> Demographic characteristics by the types of gender role identity

$n(\%)$

\begin{tabular}{|c|c|c|c|c|c|c|c|}
\hline \multirow{2}{*}{\multicolumn{2}{|c|}{$\begin{array}{c}\text { Types of gender role } \\
\text { identity } \\
\text { Demographic Variakles }\end{array}$}} & \multirow{2}{*}{\begin{tabular}{|l} 
Androgyny \\
$134(29.5)$
\end{tabular}} & \multirow{2}{*}{\begin{tabular}{|c|} 
Masculineness \\
$92(20.2)$
\end{tabular}} & \multirow{2}{*}{$\begin{array}{c}\begin{array}{c}\text { Femini- } \\
\text { neness }\end{array} \\
99(21.8)\end{array}$} & \multirow{2}{*}{$\begin{array}{c}\begin{array}{c}\text { Undifferen- } \\
\text { tiation }\end{array} \\
130(28.6)\end{array}$} & \multirow{2}{*}{$\frac{\text { Total }}{\text { 455(100) }}$} & \multirow[t]{2}{*}{$x^{2}$} \\
\hline & & & & & & & \\
\hline \multirow{2}{*}{ Gender } & Male & $79(59.0)$ & $43(46.7)$ & $36(36.4)$ & $47(36.2)$ & $205(45.1)$ & \multirow{2}{*}{$17.75 * \star \star$} \\
\hline & Female & $55(41.0)$ & $49(53.3)$ & 63(63.6) & $83(63.8)$ & $250(54.9)$ & \\
\hline \multirow{2}{*}{ Age } & $20 s$ & $74(55.2)$ & $55(59.8)$ & $70(70.7)$ & $59(45.4)$ & $258(56.7)$ & \multirow{2}{*}{$15.17 * *$} \\
\hline & $30 s$ & $60(44.8)$ & $37(40.2)$ & $29(29.3)$ & $71(54.6)$ & 197(43.3) & \\
\hline \multirow{7}{*}{ Job } & Student & $42(31.1)$ & $32(34.8)$ & $45(45.5)$ & $37(28.5)$ & $156(34.3)$ & \multirow{7}{*}{$31.70 *$} \\
\hline & Housewife & $3(2.2)$ & $2(2.2)$ & $7(7.1)$ & $9(6.9)$ & $21(4.6)$ & \\
\hline & Employee & $45(33.6)$ & $33(35.9)$ & $26(26.3)$ & $46(35.4)$ & $150(33.0)$ & \\
\hline & Professional & $8(6.0)$ & $5(5.4)$ & $3(3.0)$ & $6(4.6)$ & $22(4.8)$ & \\
\hline & $\begin{array}{l}\text { Self-owned } \\
\text { Business }\end{array}$ & $2(1.5)$ & $0(.0)$ & $1(1.0)$ & $5(3.8)$ & $8(1.8)$ & \\
\hline & $\begin{array}{c}\text { Production } \\
\text { Worker }\end{array}$ & 12(9.0) & $11(12.0)$ & $6(6.1)$ & $20(15.4)$ & $49(10.8)$ & \\
\hline & $\begin{array}{l}\text { Sales and } \\
\text { Service }\end{array}$ & $22(16.4)$ & $9(9.8)$ & $11(11.1)$ & $7(5.4)$ & $49(10.8)$ & \\
\hline
\end{tabular}

${ }^{*} \mathrm{p} \leq .05,{ }^{* *} \mathrm{p} \leq .01,{ }^{* *} \mathrm{p} \leq .001$

<Table 3> Sociocultural attitude

\begin{tabular}{|c|c|c|c|c|c|}
\hline Factors & Items & $\begin{array}{l}\text { Factor } \\
\text { loading }\end{array}$ & $\begin{array}{l}\text { Eigen } \\
\text { value }\end{array}$ & $\begin{array}{c}\text { Accumul } \\
\text { ated } \\
\text { dispersio } \\
n(\%)\end{array}$ & $\begin{array}{l}\text { Cronbach's } \alpha \\
\text { (average) }\end{array}$ \\
\hline $\begin{array}{c}\text { Internali } \\
\text { zation }\end{array}$ & $\begin{array}{l}\text { I want my body shape to be same as stars on TV. } \\
\text { I compare my body with TV stars or movie stars. } \\
\text { I want to have a great body shape just like an awesome } \\
\text { actor or actress in music video. } \\
\text { I want my looks to be like models in magazines. } \\
\text { I compare my appearance with models reading a } \\
\text { magazine for men/women. } \\
\text { Watching a music video featuring a slip woman/man, I } \\
\text { expect myself to be slim like that. } \\
\text { I also want to have a body shape as a swimsuit model. } \\
\text { I feel envious watching pictures of people with nice } \\
\text { body shape. }\end{array}$ & $\begin{array}{l}.81 \\
.80 \\
.79 \\
.78 \\
.75 \\
.75 \\
.70 \\
.69\end{array}$ & 4.71 & 42.86 & $\begin{array}{c}.91 \\
(3.30)\end{array}$ \\
\hline $\begin{array}{l}\text { Recogni } \\
\text { tion }\end{array}$ & $\begin{array}{l}\text { For a successful life in a society, the attractiveness of } \\
\text { appearance is very important. } \\
\text { The influence of the appearance comes first in the first } \\
\text { impression. } \\
\text { Appearance is very important to succeed in society. }\end{array}$ & $\begin{array}{l}.81 \\
.75 \\
.73\end{array}$ & 2.03 & 61.30 & $\begin{array}{c}.69 \\
(3.72)\end{array}$ \\
\hline
\end{tabular}


$.91-.69$ showing moderately high reliability. These two factors were named based on the items loaded highest for each factor. Factor 1 had eight statements accounting for $42.86 \%$ of the common variance. This factor was labeled as the internalization. Factor 2 had three statements and accounted for $18.44 \%$ of the common variance. This factor was labeled as the recognition.

2) The factor structure of Benefits of Clothing Pursuit
$<$ Table 4 > shows the result of factor analysis using Varimax rotation to figure out the benefits of clothing pursuit structure of twenties and thirties.

Benefits of clothing pursuit had three factors, altogether explaining $58.96 \%$ of total variance and Cronbach's alpha coefficients ranged from .86-.72 showing moderately high reliability. These three factors were named based on the items loaded highest for each factor. Factor 1 had six statements accounting for $23.14 \%$ of the common variance. This factor was labeled as the consciousness of others. Factor 2 had five

$<$ Table 4> Benefits of clothing pursuit

\begin{tabular}{|c|c|c|c|c|c|}
\hline Factors & Items & $\begin{array}{l}\text { Factor } \\
\text { Loading }\end{array}$ & $\begin{array}{l}\text { Eigen } \\
\text { Value }\end{array}$ & $\begin{array}{c}\text { Accumul } \\
\text { ated } \\
\text { dispersio } \\
\mathrm{n}(\%)\end{array}$ & $\begin{array}{c}\text { Cronbach's } \alpha \\
\text { (Average) }\end{array}$ \\
\hline $\begin{array}{c}\text { Conscio } \\
\text { usness } \\
\text { of } \\
\text { others }\end{array}$ & $\begin{array}{l}\text { I tend to choose clothes which can improve the } \\
\text { impression of mine. } \\
\text { I try to choose clothes which flatters me. } \\
\text { I care about wearing clothes for my body shape to } \\
\text { look more ideally. } \\
\text { I try to wear nice clothes to give a good } \\
\text { impression. } \\
\text { I buy clothes which makes me comfortable and } \\
\text { gives me self-confidence. } \\
1 \text { I express my image through clothes. }\end{array}$ & $\begin{array}{l}.81 \\
.73 \\
.71 \\
.70 \\
.70 \\
.67\end{array}$ & 3.47 & 23.14 & $\begin{array}{c}.86 \\
(3.49)\end{array}$ \\
\hline $\begin{array}{c}\text { Personali } \\
\text { ty } \\
\text { pursuit }\end{array}$ & $\begin{array}{l}\text { I try to wear unique clothes unlike the common } \\
\text { style of most people. } \\
\text { I enjoy wearing clothes which are new and unique. } \\
\text { I tend to wear clothes differentiated from others. } \\
\text { My friends and neighbors sometimes ask me some } \\
\text { feedbacks about vogue. } \\
\text { I tend to influence on the style of clothes my } \\
\text { friends are buying. }\end{array}$ & $\begin{array}{l}.82 \\
.77 \\
.73 \\
.61 \\
.57\end{array}$ & 3.07 & 43.58 & $\begin{array}{c}.82 \\
(2.75)\end{array}$ \\
\hline $\begin{array}{l}\text { Vogue } \\
\text { pursuit }\end{array}$ & $\begin{array}{l}\text { It's important to wear clothes according to present } \\
\text { trend. } \\
\text { I tend to choose a well-known brand. } \\
\text { I think it important to wear clothes of new fashion } \\
\text { style to keep fashion-oriented image. } \\
\text { To belong the class I want, I should wear clothes } \\
\text { similar to the ones the members of the class are } \\
\text { wearing. }\end{array}$ & $\begin{array}{l}.74 \\
.71 \\
.68 \\
.62\end{array}$ & 2.31 & 58.96 & $\begin{array}{c}.72 \\
(2.85)\end{array}$ \\
\hline
\end{tabular}


Park Eunhee / A Study on Sociocultural Attitudes and Appearance Management Behavior in accordance with Gender Role Identity

statements and accounted for $20.44 \%$ of the common variance. This factor was labeled as the personality pursuit. Factor 3 had four statements and accounted for $15.38 \%$ of the common variance. This factor was labeled as the vogue pursuit.

\section{3) Factor structure of Appearance Management Behaviors}

$<$ Table $5>$ shows the result of factor analysis using Varimax rotation to figure out the appearance management behaviors structure of twenties and thirties.

<Table 5> Appearance management behaviors

\begin{tabular}{|c|c|c|c|c|c|}
\hline Factors & Items & $\begin{array}{l}\text { Factor } \\
\text { Loading }\end{array}$ & $\begin{array}{l}\text { Eigen } \\
\text { Value }\end{array}$ & $\begin{array}{l}\text { Accumulat } \\
\text { ed } \\
\text { Dispersion } \\
(\%)\end{array}$ & $\begin{array}{l}\text { Cronbach's } \alpha \\
\text { (Average) }\end{array}$ \\
\hline Dressing & $\begin{array}{l}\text { I check my dressing before going out in front of } \\
\text { others. } \\
\text { Usually I have much interest in clothes others are } \\
\text { wearing. } \\
\text { I purchase clothes which go well with clothes that } \\
\text { I already have. } \\
\text { I try my best to be said that I am well-dressed. } \\
\text { I often check my appearance through a mirror. }\end{array}$ & $\begin{array}{l}.80 \\
.75 \\
.73 \\
.71 \\
.69 \\
\end{array}$ & 3.38 & 14.68 & $\begin{array}{c}.85 \\
(3.49)\end{array}$ \\
\hline $\begin{array}{l}\text { Skin } \\
\text { Managem } \\
\text { ent }\end{array}$ & $\begin{array}{l}\text { I use functional cosmetics for skin management } \\
\text { everyday. } \\
\text { I frequently get skin massage on my face. } \\
\text { I never go out without sun-blocker on my face. } \\
\text { I have used a professional skin care shop. }\end{array}$ & $\begin{array}{l}.77 \\
.73 \\
.69 \\
\end{array}$ & 2.93 & 27.42 & $\begin{array}{c}.83 \\
(2.69)\end{array}$ \\
\hline $\begin{array}{c}\text { Plastic } \\
\text { Surgery } \\
\text { Managem } \\
\text { ent }\end{array}$ & $\begin{array}{l}\text { Plastic surgery is important for improving a body } \\
\text { image. } \\
\text { It's worth having a plastic surgery for a } \\
\text { successful social life. } \\
\text { I become to want to have a plastic surgery } \\
\text { watching celebrities. } \\
\text { I'm interested in plastic surgery for improving } \\
\text { appearance. }\end{array}$ & $\begin{array}{l}.83 \\
.81 \\
.76 \\
.68\end{array}$ & 2.79 & 39.53 & $\begin{array}{c}.84 \\
(2.88)\end{array}$ \\
\hline $\begin{array}{l}\text { Weight } \\
\text { Managem } \\
\text { ent }\end{array}$ & $\begin{array}{l}\text { I exercise periodically to maintain a slip body } \\
\text { shape. } \\
\text { I have skipped meals for a diet. } \\
\text { I exercise to shape a good looking body. } \\
\text { I try various ways of diet for a slim body shape. } \\
\text { I never eat something of my favorite if it makes } \\
\text { me weigh more. }\end{array}$ & $\begin{array}{l}.71 \\
.68 \\
.67 \\
.65 \\
.62\end{array}$ & 2.62 & 50.91 & $\begin{array}{l}.79 \\
(2.44)\end{array}$ \\
\hline $\begin{array}{c}\text { Health } \\
\text { Managem } \\
\text { ent }\end{array}$ & $\begin{array}{l}\text { I tend to be picky in eating food good for health. } \\
\text { I try to read and watch the articles or programs } \\
\text { about health. } \\
\text { I regularly take vitamins or nutrients. }\end{array}$ & $\begin{array}{l}.82 \\
.75 \\
.71 \\
\end{array}$ & 2.26 & 60.72 & $\begin{array}{c}.79 \\
(2.86)\end{array}$ \\
\hline $\begin{array}{c}\text { Hair } \\
\text { managem } \\
\text { ent }\end{array}$ & $\begin{array}{l}\text { I often use hair styling products such as mousse, } \\
\text { hair spray, hair-gel and etc. } \\
\text { I style my hair with a hair dryer often. }\end{array}$ & $\begin{array}{l}.83 \\
.74 \\
\end{array}$ & 1.45 & 67.02 & $\begin{array}{l}.57 \\
(2.70)\end{array}$ \\
\hline
\end{tabular}


Appearance management behaviors had six factors, altogether explaining $67.02 \%$ of total variance and Cronbach's alpha coefficients ranged from .85-.57 showing reliability. These six factors were named based on the items loaded highest for each factor. Factor 1 had five statements accounting for $14.68 \%$ of the common variance. This factor was labeled as the dressing. Factor 2 had four statements and accounted for $12.74 \%$ of the common variance. This factor was labeled as the skin management. Factor 3 had four statements and accounted for $12.11 \%$ of the common variance. This factor was labeled as the plastic surgery management. Factor 4 had five statements and accounted for $11.38 \%$ of the common variance. This factor was labeled as the weight management. Factor 5 had three statements and accounted for $9.81 \%$ of the common variance. This factor was labeled as the health management. Factor 6 had four statements and accounted for $6.30 \%$ of the common variance. This factor was labeled as the hair management.

\section{The difference between Sociocultural Attitude and Benefits of Clothing pursuit by sense of Gender Role Identity Types}

$<$ Table 6> shows the result of single-variable analysis and Duncan test to find out the difference between sociocultural attitude and benefits of clothing pursuit. by sense of gender role identity types. There was no significant difference of internalization by sense of gender role identity types in men whereas significant difference in women. Women of androgyny turned out to have more desire to have a same looking body as celebrities on TV than women of undifferentiation group. There was a significant difference of recognition by sense of gender role identity types in both men and women. Men of androgyny group and feminineness group think that for a success appearance should be attractive and the first impression affects appearance much. Men of undifferentiation group and masculineness group take the social importance of appearance low. Women of androgyny have high recognition of social importance of appearance whereas women of undifferentiation group lowest. This result is correspondent with Kim Yongsook's study which suggested adult women of undifferentiation group evaluate interest and attractiveness toward their appearance lower than other groups. ${ }^{38)}$ Women have high tendency

$<$ Table 6> Sociocultural attitude by sense of gender role identity types

$(\mathrm{N}=455)$

\begin{tabular}{c|c|c|c|c|c|c}
\hline $\begin{array}{r}\text { Types of gender role } \\
\text { identity }\end{array}$ & Androgyny & Masculineness & Feminineness & $\begin{array}{c}\text { Undifferentiatio } \\
\mathrm{n}\end{array}$ & F-value \\
\hline \multirow{2}{*}{ Sociocultural attitude } & $\mathrm{M}$ & $3.19^{\mathrm{a}} \mathrm{A}^{\mathrm{b}}$ & $2.94 \mathrm{~A}$ & $3.18 \mathrm{~A}$ & $2.94 \mathrm{~A}$ & 1.92 \\
\hline \multirow{2}{*}{ Recognition } & $\mathrm{F}$ & $3.78 \mathrm{~A}$ & $3.53 \mathrm{AB}$ & $3.52 \mathrm{AB}$ & $3.26 \mathrm{~B}$ & $5.74^{\star \star \star}$ \\
\cline { 2 - 7 } & $\mathrm{M}$ & $3.73 \mathrm{~A}$ & $3.43 \mathrm{~B}$ & $3.70 \mathrm{~A}$ & $3.35 \mathrm{~B}$ & $5.18^{\star \star}$ \\
\hline \hline
\end{tabular}

${ }^{* *} \mathrm{p} \leq .01,{ }^{* * *} \mathrm{p} \leq .001$

$a=$ average score by the groups, $b=$ literally indicated result of Duncan test $(A>B>C)$ 
Park Eunhee / A Study on Sociocultural Attitudes and Appearance Management Behavior in accordance with Gender Role Identity

of internalizing the ideal social standards delivered through mass media into their own values and high recognition of social importance that appearance. This result is also correspondent with the result of Lee Seunghee and Lee Siweon's study. ${ }^{39)}$

$\langle$ Table $7>$ shows the result of single-variable analysis and Duncan test to find out the difference in benefits of clothing pursuit. by sense of gender role identity types. There was a significant difference both in men and women of being conscious of others group and men of androgyny group tended to choose clothes which can improve their impression or flatter them while men of undifferentiation group and masculineness group had low interest in dressing for a relationship with others. This result is correspondent with the result of $\mathrm{Ku}$ Yangsuk, Lee Young Ju and Choo Taegue's study which suggested that The more feminine men of androgyny group and feminineness group are, the more important motives personal relations, competitiveness, and acknowledgement of others are for appearance management. ${ }^{40)}$ Women of androgyny group turned out to be more interested in dressing of others thinking that their own dressing is important, and women of undifferentiation group had low interest in dressing. There was a significant difference in personality pursuit and vogue pursuit by sense of gender role identity types both in men and women. Men of androgyny group wear clothes of newer or more unique style than other groups and choose clothes of high fashioned style from a famous brand. Women of androgyny group and masculineness group pursue high evaluation of their sense of beauty by affecting the clothing style which friends are going to buy. This result is correspondent with the result of Kim Yongsook's study that women of androgyny group and masculineness group originally have high masculineness inside and they are self-confident and have high desire in personality so they might evaluate interest in their appearance and the attractiveness. ${ }^{41)}$ This is also in the same context with the result of Choi Miyoung's study that active masculineness pursuit would be related to vogue-conviction as it has a characteristics which values important on self-expression and self-satisfaction enjoying vogue itself because women of androgyny group are high in vogue pursuit. ${ }^{42)}$

\section{$<$ Table $7>$ Benefits of clothing pursuit by sense of gender role identity types}

$(\mathrm{N}=455)$

\begin{tabular}{|c|c|c|c|c|c|c|}
\hline \multicolumn{2}{|c|}{$\begin{array}{l}\text { Types of gender role } \\
\text { identity } \\
\text { Benefits of clothing } \\
\text { pursuit }\end{array}$} & Androgyny & Masculineness & Feminineness & Undifferentiation & F-value \\
\hline \multirow{2}{*}{$\begin{array}{c}\text { Consciousnes } \\
\mathrm{s} \text { of others }\end{array}$} & $M$ & $3.60^{a} A^{b}$ & $3.19 \mathrm{~B}$ & $3.34 \mathrm{~B}$ & $3.13 \mathrm{~B}$ & $6.74^{\star \star \star}$ \\
\hline & $\mathrm{F}$ & $3.96 \mathrm{~A}$ & $3.67 \mathrm{~B}$ & $3.58 \mathrm{~B}$ & $3.31 \mathrm{C}$ & $15.58^{\star \star \star}$ \\
\hline \multirow{2}{*}{$\begin{array}{l}\text { Personality } \\
\text { Pursuit }\end{array}$} & $M$ & $2.89 \mathrm{~A}$ & $2.53 \mathrm{~B}$ & $2.53 \mathrm{~B}$ & $2.46 \mathrm{~B}$ & $4.17^{\star \star}$ \\
\hline & $\mathrm{F}$ & $3.19 \mathrm{~A}$ & $3.04 \mathrm{~A}$ & $2.76 \mathrm{~B}$ & $2.50 \mathrm{C}$ & $13.31^{\star \star \star}$ \\
\hline \multirow{2}{*}{ Vogue Pursuit } & $M$ & $3.09 \mathrm{~A}$ & $2.60 \mathrm{~B}$ & $2.58 \mathrm{~B}$ & $2.82 \mathrm{AB}$ & $6.37^{\star \star \star}$ \\
\hline & $\mathrm{F}$ & $3.10 \mathrm{~A}$ & $2.89 \mathrm{~B}$ & $2.80 \mathrm{~B}$ & $2.70 \mathrm{~B}$ & $4.56^{\star \star}$ \\
\hline
\end{tabular}

${ }^{* *} \mathrm{p} \leq .01,{ }^{* * *} \mathrm{p} \leq .001$

$a=$ average score by the groups, $b=$ literally indicated result of Duncan test $(A>B>C)$ 


\section{The difference in Appearance Management Behaviors by sense of Gender Role Identity Types}

$<$ Table $8>$ shows the result of single-variable analysis and Duncan test to find out the difference in appearance management behaviors by sense of gender role identity types. Men and women both have a significant difference in dressing by sense of gender role identity types and men of androgyny group and feminineness group appeared to check their dressing before they go out in front of others or they have high interest in others' dressing while men of undifferentiation group and masculineness group are not interested in dressing in personal relations. This result is similar to the result of Lee Yoonjung's study that they are not that feminine comparing to the ones who are not interested in appearance even though they seem to accept the feminine appearance code showing interest much in appearance. ${ }^{43)}$ Women of androgyny takes their dressing important and they have much interest in others' dressing while women of other groups do not. There's a significant difference in skin management among men but there's no significant difference among women. Men of androgyny take skin care most frequently but other groups do not. The reason why there was no significant difference in skin care among women might be that most of women are much interested in skin management, so they purchase functional cosmetics or take a skin massage regardless of sense of types of gender role identity. The same goes for the plastic surgery item. In weight management a

<Table 8> Appearance management behaviors by the types of gender role identity

$(\mathrm{N}=455)$

\begin{tabular}{|c|c|c|c|c|c|c|}
\hline \multicolumn{2}{|c|}{$\begin{array}{c}\text { Types of gender } \\
\text { role identity } \\
\text { Appearance } \\
\text { Management }\end{array}$} & \multirow{2}{*}{$\begin{array}{l}\text { Androgyny } \\
3.51^{a} A^{b}\end{array}$} & \multirow{2}{*}{$\begin{array}{c}\text { Masculineness } \\
2.98 \mathrm{~B} \\
\end{array}$} & \multirow{2}{*}{$\begin{array}{c}\text { Feminineness } \\
3.49 \mathrm{~A}\end{array}$} & \multirow{2}{*}{$\begin{array}{l}\text { Undifferentiation } \\
2.94 \mathrm{~B}\end{array}$} & \multirow{2}{*}{$\frac{F-\text { value }}{10.18^{\star \star \star}}$} \\
\hline & $M$ & & & & & \\
\hline Uressing & $\mathrm{F}$ & $3.96 \mathrm{~A}$ & $3.69 \mathrm{~B}$ & $3.65 \mathrm{~B}$ & $3.48 \mathrm{~B}$ & $6.55^{\star \star \star}$ \\
\hline \multirow{2}{*}{ Skin care } & $M$ & $2.41 \mathrm{~A}$ & $2.03 \mathrm{~B}$ & $1.92 \mathrm{~B}$ & $2.11 \mathrm{AB}$ & $3.35^{*}$ \\
\hline & $F$ & $3.18 \mathrm{~A}$ & $3.15 \mathrm{~A}$ & $3.06 \mathrm{~A}$ & $3.07 \mathrm{~A}$ & .30 \\
\hline \multirow{2}{*}{$\begin{array}{c}\text { Plastic } \\
\text { Surgery } \\
\text { Manageme } \\
\text { nt }\end{array}$} & $M$ & $2.72 \mathrm{~A}$ & $2.48 \mathrm{~A}$ & $2.58 \mathrm{~A}$ & $2.60 \mathrm{~A}$ & .88 \\
\hline & $\mathrm{F}$ & $3.23 \mathrm{~A}$ & $3.07 \mathrm{~A}$ & $2.99 \mathrm{~A}$ & $3.11 \mathrm{~A}$ & .92 \\
\hline \multirow{2}{*}{$\begin{array}{c}\text { Weight } \\
\text { Manageme } \\
\mathrm{nt}\end{array}$} & $\mathrm{M}$ & $2.58 \mathrm{~A}$ & $2.32 \mathrm{AB}$ & $2.26 \mathrm{AB}$ & $2.27 \mathrm{~B}$ & $2.19^{*}$ \\
\hline & $\mathrm{F}$ & $2.58 \mathrm{~A}$ & $2.60 \mathrm{~A}$ & $2.44 \mathrm{~A}$ & $2.33 \mathrm{~A}$ & 1.89 \\
\hline \multirow{2}{*}{$\begin{array}{c}\text { Health } \\
\text { Manageme } \\
\mathrm{nt}\end{array}$} & $\mathrm{M}$ & $3.12 \mathrm{~A}$ & $2.55 \mathrm{~B}$ & $2.79 \mathrm{AB}$ & $2.67 \mathrm{~B}$ & $5.19^{\star \star}$ \\
\hline & $\mathrm{F}$ & $3.26 \mathrm{~A}$ & $2.87 \mathrm{~B}$ & $2.85 \mathrm{~B}$ & $2.63 \mathrm{~B}$ & $6.37^{\star \star \star}$ \\
\hline \multirow{2}{*}{$\begin{array}{c}\text { Hair } \\
\text { Manageme } \\
\mathrm{nt}\end{array}$} & $M$ & $3.20 \mathrm{~A}$ & $2.70 \mathrm{~B}$ & $2.61 \mathrm{~B}$ & $2.64 \mathrm{~B}$ & $5.01^{\star \star}$ \\
\hline & $\mathrm{F}$ & $2.40 \mathrm{~A}$ & $2.55 \mathrm{~A}$ & $2.52 \mathrm{~A}$ & $2.55 \mathrm{~A}$ & .39 \\
\hline
\end{tabular}

${ }^{*} \mathrm{p} \leq .05,{ }^{* *} \mathrm{p} \leq .01,{ }^{* * *} \mathrm{p} \leq .001$

$a=$ average score by the groups, $b=$ literally indicated result of Duncan test $(A>B)$ 
Park Eunhee / A Study on Sociocultural Attitudes and Appearance Management Behavior in accordance with Gender Role Identity

significant difference was found only in men. Men of androgyny group turned out to care more about weight than other groups, which is correspondent with the result of $\mathrm{Ku}$ Yangsuk, Lee Young Ju and Choo Taegue's study ${ }^{44)}$ that people in androgyny group have more interest in appearance than other groups and they actively exercise to lose weight and to maintain the body shape. In appearance management behaviors, there was no significant difference found among women, which can be understood that women in modern society think a slim body shape to be ideal, so they try to control weight even though they don't need. This is correspondent with the result of Kim Hyunjeoung and Lee Myounghee's study. ${ }^{45)}$ The difference in health management was significant in both men and women. Androgyny group seems to manage health eating good food as they have high self-confidence and strong will as well as soft and mild nature. On the other hand, undifferentiation group does not try much on health management as people of the group are convicted with their health or they don't have self-confidence. The difference in hair management was significant only in men and men of androgyny use hair styling product more often. This is correspondent with the results of Kim and Lee's study and Ku Yangsuk, Lee Young Ju and Choo Taegue's study that androgyny group have higher scores in all factors than other groups so that their activity is dynamic. $^{46)}$

\section{Conclusion and Implications}

This study was to examine men and women separately and to find out the sense of their sociocultural attitude toward appearance and managing their appearance by sense of gender role identity types. The results and implications of the study can be summarized as follows.

First, Men in androgyny group were the highest in rate, 38.5\%, which have a characteristics of trustful, sincere mind and strong will and at the same time a characteristics of soft and mild heart. Men of undifferentiation group who are not soft nor delicate with weak will and low locomotive were $22.9 \%$, and men of masculineness group who are of decision with high locomotive were $21.0 \%$, men of feminineness group who are just typical women with delicate emotion and softness showed the lowest rate, 17.6\%. In women's cases, women of undifferentiation group who have weak self-confidence and willingness and are not kind nor obedient showed the highest rate of $33.2 \%$ followed by feminineness (25.2\%), androgyny(22.0\%), and masculineness(19.6\%).

Second, factors of sociocultural attitude were internalization and recognition. Factors of benefits of clothing pursuit were consciousness of others, personality, and vogue pursuit. Factors of appearance management behaviors were dressing, skin management, plastic surgery management, weight management, health management, and hair management.

Third, the result from the difference between sociocultural attitude and benefits of clothing pursuit by sense of gender role identity types, men of androgyny and feminineness showed highest in recognition while women of androgyny showed highest in internalization and recognition. This means that men of androgyny group who have high motivation and emotion at the same time and men of feminineness who are kind and tender consider the attractiveness of appearance to be important while women of androgyny who 
have high motivation and emotion at the same time seemed to want to have a body shape just like a TV star considering the appearance to be most important. The undifferentiation group has low interest in sociocultural attitude.

The result of the difference in benefits of clothing pursuit by sense of gender role identity shows that both men and women of androgyny group have high tendency for being consciousness of others, personality pursuit, and vogue pursuit while men of undifferentiation and masculineness have low interest in dressing in relationship with others. Both men and women of androgyny highly tend to choose clothes that can flatter them or improve their impression and they evaluate their own sense of beauty high affecting the clothes style of others or wearing new and unique styled clothes.

Fourth, the examination of the difference in appearance management behavior by sense of gender role identity types found men of androgyny group managed dressing, skin, weight, health and hair most while women dress and health most. Men of undifferentiation group managed dressing and weight least, while men of masculineness health, and men of feminineness hair least.

According to the result, men and women in their twenties and thirties who have androgyny with both characteristics of strong will and trustfulness and gentle and kind tried to form a positive image putting a high value on attractive appearance in social life as this is an important cue for a social position or getting a job. Men of androgyny are not only interested much in outlooks of dressing but also eager to challenge new one and accept fashion trends actively to form a positive image valuating their own sense of beauty.
Men with a harmoniously-developed masculineness and feminineness flexibly accept the value system toward changing appearance and aim for a wanted appearance from modern society. In other words, they manage their appearance for a good dressing by managing weight, intaking foods good for body to maintain healthy body, using functional cosmetics or having a frequent skin massage for skin, and having a high involvement in hair management.

Therefore, it can be said that the result of this study showed appearance is practically a tool for being socially successful promoting oneself and it also showed different eyes of men on appearance. On the other hand, women mostly got interested in skin and very sensitive on weight, and managed hair with much interest, in which a difference by the sense of gender role identity was not found.

Women with a harmoniously-developed masculineness and feminineness thoroughly managed their health conditions and had high intention to show their nice appearance by checking their dressing before meeting others. Accordingly appearance-related industry and fashion companies orienting men in 20s and 30s should suggest a specific marketing strategy for a masculine characteristics considering the positive side of feminineness, while womenoriented companies should suggest a specific marketing strategy for appearance management accepting masculineness and feminineness in harmony rather than putting an emphasis on feminineness. The limitation of this study is generalization of the result since the subjects are in their twenties and thirties, which suggests an opportunity for a study including various age groups. 
Park Eunhee / A Study on Sociocultural Attitudes and Appearance Management Behavior in accordance with Gender Role Identity

\section{Reference}

1) Bem, S. L.(1974), "The measurement of psychological androgyny", Journal of Consulting and Clinical Psychology, 42, pp.155-162.

2) Yoon Euna, Lee Sunjae(2000), “A Study on Clothing Behavior and Clothing Image of Out/Inner Wear According to Sex Role Stereotype", Journal of the Korean Society of Clothing and Textiles, 24(2), pp.152-163.

3) Kim Yongsook(2009), "Body Image and Cosmetic Image Based on Women's sex Role Identity", Journal of the Korean Society of Costume, 59(3), pp.55-66.

4) Choi Miyoung(2010), "A Study on the Clothing Involvement and Clothing Consumption Behavior of Female University Students according to Gender Role Attitude“, Journal of the Korean Society of Costume, 60(8), pp.15-28.

5) Lee Yoonjung(2007), "Male Consumers' Motives of Appearance Management Behavior-Focused on Their Sex Role Identities and Benefit Sought on Clothing-", Journal of the Korean Society of Clothing and Textiles, 31(4), pp.551-562.

6) Lee Youngju(2011), “Bag Preference of Men according to their Age and Gender-role Identity Types", Journal of the Korean Society for Clothing Industry, 13(1), pp.82-90.

7) Lee Hyunji, Park Oklyun(2005), "The factor of feminization in men's fashion according to Sex Role Stereotype-research about 20's 30's mens-", Korean Journal of Human Ecology, 14(6), pp.1027-1035.

8) Lee Yoonjung(2005), "Clothing Shopping Orientation and Sex Role Identity of Male
Consumers Aged Between 20 and 40", Korean Home Economic Association, 43(9), pp.27-40.

9) Nam Sujung(2010), "Metro-sexual Consumption in Accordance with Identity of Gender Roles, Self-esteem and Culturalsocial Attitude toward Appearance", Korean Journal of Human Ecology, 19(1), pp.91-102.

10) Yoon Euna, Lee Sunjae, op.cit., pp.152-163.

11) Kim Yongsook, op.cit., pp.55-66.

12) Choi Miyoung, op.cit., pp.15-28.

13) Lee Misook(2008), "The Effects of Gender-Role Identity on Adolescents' Self Esteem, Clothing Behaviors and Favorite Clothing Image-Focused on analysis by adolescent' sex and age variable-", Korean Journal of Human Ecology, 17(4). pp.707-721.

14) Kim Hyunjeoung, Lee Myounghee(2010), “A Study of Appearance Management Behaviors and Body Exposure Attitudes according to Sex Role Identity", Journal of the Korean Society of Costume, 60(3), pp.99-109.

15) Ibid., pp.99-109.

16)Bem, S. L., op.cit., pp.155 162.

17) Chang Hakyung, Seo Byongsook(1991), "A Study on the Sex-Role Identity Inventory", Korean Home Economic Association, 29(4), pp. 167-179.

18) Lee Yoonjung, op.cit., pp.27-40.

19) Lee Misook, op.cit., pp.707-721.

20) Ku Yangsuk, Lee Youngju, Choo Taegue (2011), “A Study on Appearance Management Behavior of Male Consumers (III)-Focusing on the Gender Role Identity-", Journal of the Korean Society for Clothing Industry, 13(2), pp.226-233.

21) Leslie J. Heinberg, J. Kevin Thompson, and Susan Stormer(1995), "Development and 
Validation of the Sociocultural Attitudes Towards Appearance Questionnaire", International Journal of Eating Disorders, 17(1), pp.81-89.

22) Lee Seunghee, Lee Siweon(2009), "Public Self-Consciousness, Body Image, \& Socio-Cultural Influence on Gender Differences", Journal of Fashion Business, 13(5), pp.45-54.

23) Kim Yongsook, op.cit., pp.55-66.

24) Nam Sujung, op.cit., pp.91-102.

25) Lee Yoonjung, op.cit., pp.551-562.

26) Lee Jinkyung(2008. 02. 01.), "Alpha girl, gold miss, pet-man, the dissolution of traditional gender role", The Segye.com, Retrieved 2011. 06. 05, from http://search2.segye.com

27) Choi Miyoung, op.cit., pp.15-28.

28) Lee Yoonjung, op.cit., pp.551-562.

29) Kim Hyunjeoung, Lee Myounghee, op.cit., pp.99-109.

30) Ku Yangsuk, Lee Youngju, Choo Taegue, pp.226-233.

31) Leslie J. Heinberg, J. Kevin Thompson, and Susan Stormer, op.cit., pp.81-89.

32) Hwang Yunjung, Yoo Taisoon(2010), "The effects of Sociocultural Attitudes Toward Appearance, Self-Esteem, and Physical Attractiveness Perceptiveness on Weight and Clothing Management Behaviors", Journal of the Korean Society of Clothing and Textiles, 34(11), pp.1923-1932.

33) Lee Snagsun, Oh Kyungja(2003), "Validation study of the Sociocultural Attitudes towards Appearance Questionnaire in Korea", The Korean Journal of Clinical Psychology, 22(4), pp.913-926.
34) Park Eunhee(2012), "The Effects of Sociocultural Attitude toward Appearance and Pursuit of Clothing Benefits on Ambivalent Consumption of Fashion Product", Journal of Fashion Business, 16(1), pp.137-149.

35) Kim Hyunjeoung, Lee Myounghee, op.cit., pp.99-109.

36) Jeon Hyunjin, Chung Myungsun(2010), "The Effects of Sociocultural Attitudes Toward Appearance and Objected Body Consciousness on the Behavior of 20 30's Women for Appearance Management", Journal of the Korean Society of Cosmetology, 16(2), pp.590-601.

37) Ku Yangsuk, Lee Youngju, Choo Taegue, op.cit., pp.226-233.

38) Kim Yongsook, op.cit., pp.55-66.

39) Lee Seunghee, Lee Siweon, op.cit., pp.45-54.

40) Ku Yangsuk, Lee Youngju, Choo Taegue, op.cit., pp.226-233.

41) Kim Yongsook, op.cit., pp.55-66.

42) Choi Miyoung, op.cit., pp.15-28.

43) Lee Yoonjung, op.cit., pp.551-562.

44) Ku Yangsuk, Lee Youngju, Choo Taegue, op.cit., pp.226-233.

45) Kim Hyunjeoung, Lee Myounghee, op.cit., pp.99-109.

46) Ku Yangsuk, Lee Youngju, Choo Taegue, op.cit., pp.226-233.

Received Jul. 10, 2012

Revised (Jul. 17, 2012)

Accepted Jul. 19, 2012 